\title{
Hotel za insekte - razvijanje međupredmetnih kompetencija kroz projektnu nastavu
}

\author{
Ana R. Jeremić \\ PHS „Dr Đorđe Radić", Kraljevo i OŠ „IV kraljevački bataljon“, Kraljevo, Srbija \\ Nataša M. Vukovič \\ OŠ „IV kraljevački bataljon", Kraljevo, Srbija
}

\begin{abstract}
Apstrakt
Kako je u uslovima dinamičkih društvenih i tehnoloških promena, potrebno uvođenje angažovanijeg procesa konstrukcije znanja u realnom okruženju (Popović i Ristanović, 2020), projektna nastava je oblik nastavnog rada koji omogućava razvoj predmetnih i međupredmetnih kompetencija potrebnih za funkcionisanje u realnim životnim uslovima. $U$ radu je opisan primer dobre prakse tj. tok radionice, planirane i realizovane u okviru projektne nastave. Radionica je namenjena učenicima 4,5 i 6 . razreda osnovne škole sa ciljem da se kroz kreativnu radionicu - izrada hotela za insekte, učenicima približe informacije o značaju i položaju insekata u prirodi. Aktivnosti su osmišljene tako da kod učenika probude interesovanje za prirodu i nauku, da se dobro zabave i da kroz igru i drvene konstrukcije, razvijaju svest o važnosti insekata u prirodi, kao i o ugroženosti nekih vrsta. Takođe, jedan od ciljeva da samostalno osmisle način kako da povećaju brojnost insekata, da otkriju zašto su insekti značajni za održavanje ravnoteže u prirodi, da osmisle kako da u svojoj bašti naprave samostalno hotel za insekte i od kojih materijala, da razviju interesovanje i motivisanost za posmatranje, proučavanje i zaštitu vrsta insekata u njihovom prirodnom staništu. Pored predmetnih, ovakav način učenja učenika uticao je i na razvijanje međupredmetnih kompetencija-koje se u najvećoj meri odnose na komunikaciju, saradnju, odgovoran odnos prema okolini i zdravlju, rešavanje problema, preduzetničke veštine i druge.
\end{abstract}

Ključne reči: projektna nastava, predmetne i međupredmetne kometencije, radionica, hotel za insekte.

„Ako pčele nestanu s planete Zemlje, čoveku kao vrsti ostaće jos oko četiri godine života."

Albert Ajnštajn

\section{Uvod}

Za praktično otkrivanje znanja, primenu tih stečenih znanja i razvijanje međupredmetnih kompetencija treba pre svega obezbditi adekvatno okruženje za učenje. U skladu sa tim osmišljena je radionica simboličnog i motivišućeg naziva „Pansion slobodan let“. Ova radionica, koja podrazumeva izradu hotela za insekte, pre svega ima zadatak realizaciju nastavnih i vannastavnih aktivnosti, i da se, kombinacijom individualnih i grupnih aktivnosti, razvija lična i kolektivna odgovornost učenika (Popović $i$ Ristanović, 2020). Kroz postupak izrade hotela, pripreme i odabira materijala, razvijamo saradnju i sposobnost rešavanja problema. Projektnim aktivnostima, učenici se upoznaju se položajem, ulogom i 
značajem insekata u prirodi, čime se razvija odgovoran odnos prema okolini i svest da ljudi nisu sami i jedini u prirodi, već da smo deo lanca ishrane i da zavisimo od drugih vrsta. "Smatra se da je oko 30\% hrane koju ljudi svakodnevno jedu direktno ili indirektno povezano s oprasivanjem koje obavljaju pčele" (Subakov- Simić i Drndarski, 2019: 72) Ključno je da se povežu stečena znanja iz različitih oblasti i da se do rešenja dolazi istraživanjem i primenom naučenog. Takođe su važna iskustvena saznanja, koje mere i aktivnosti mogu kao pojedinci preduzeti, da rad u timu daje bolje rezultate, a saradnja i razmena iskustava dovode do resenja problema. Kroz igru, podelu zadataka i uloga, učenici takođe otkrivaju novi način učenja i upoznavanja živog sveta oko nas. Kroz postupak izrade hotela za insekte razvijamo i kompetenciju za rešavanje problema i saradnju. Na osnovu iskustva stečenog van škole, na osnovu istraživačkog rada učenika, koristeći različite izvore (internet strane, časopise, enciklopedije...) učenici osmišljavaju moguća rešenja, diskutuju o mogućim rešenjima, uče kako da saslušaju sagovornika i drugačije poglede na moguća rešenja problema, prihvataju različite poglede kako se projekat može realizovati, uočavaju slabe i dobre strane predloženih rešenja i biraju najbolje. Kroz projekat uče kako da na nivou grupe donesu odluku, kako da odrede cilj projekta (koje insekte žele da privuku odabranim izgledom hotela i zašto). Nastavnik usmerava rad učenika i podstiče učenike da svaki učenik doprinese kreativno radu grupe, da pomogne u rešavanju i prevazilaženju razlike u mišljenjima kako hotel za insekte treba da izgleda. Kroz ovakav vid nastave razvijamo saradnju izmedju učenika, podstičemo učenike da se konačne odluke i zaključci donose na nivou grupe gde argumentovano navode zašto su izabrali baš takav raspored u hotelu, koji materijal je najbolji i zašto.

Realizacijom projekta takođe razvijamo kod učenika odgovoran odnos prema zdravlju i odgovoran odnos prema okolini.Učenici prikupjaju informacije o značaju hotela za insekte u organskoj proizvodnji i smanjenoj upotrebi pesticida, istražuju primere dobre prakse i otkrivaju kako bez upotrebe pesticida možemo zahvaljujuci povecanju broja insekata dobiti dobar prinos na njivi ili u vocnjaku. Cilj je da kroz projekat promovišemo zdravlje i zdrave stilove života, da učenici uoče međuzavisnost živog sveta i značaj očuvanja biodiverziteta. Izvode zaključke kako svojim radom i aktivnostima mogu da doprinesu povećanju broja insekata, kako da unaprede životnu sredinu i doprinesu održivom razvoju. Učestvovanjem u projektu pokazuju svoju spremnost za angažovanje u zaštiti prirode i biodiverziteta. Rezultat projekta je produkt - hotel za insekte koji ima jasnu upotrebnu vrednost i kroz čije predstavljanje drugim učenicima saljemo poruku da moraju delovati u smeru održivog razvoja - da uzimaju od prirode samo onoliko koliko im je potrebno, da deluju pojedinačno i kolektivno u cilju povecanja i očuvanja biodiverziteta, da bi ostavili nesto i za buduće generacije. lako ovde nisu našle centralno mesto, ovaj proejekta u manjoj meri razvija i digitalne kompetencije učenika, jer je potrebno prikupljanje informacije iz različitih izvora. Nenametljivo od učenika se traži analizi materijala, povezivanje i primena znanja iz više predmeta. Učenici prilagodjavaju način komunikacije na nivou grupe i kroz rad razvijaju kompetenciju za komunikaciju, doprinose negovanju kulture dijaloga u grupnom radu, uvažavaju različitosti, imaju razvijenu svest o značaju pozitivne komunikacije i koliko im može pomoći pri realizaciji zadatka.

\section{Teorijsko utemeljenje}

\section{Projektna nastava}

U svojoj osnovi projektna nastava se oslanja na filozofiju pragmatizma koja je nastala u periodu snažnog industrijskog razvoja. Sam naziv nastao je od grčke reči pragma što znači delo, praksa. Od svih filozofa tog pravca, za obrazovanje je najznačajniji Džon Djui. On u svom radu ima i teorijski i praktični aspekt bavljenja nastavom i obrazovanjem. Zapravo u svom radu Djui je nastojao da se u školi ne koriste samo knjige, tj. da ne postoji samo teorijski aspekt škole, već da se on dopuni praktičnim 
radom i da srž školskog rada bude aktivnost učenika i na samostalnom otkrivanju znanja.

Projektna nastava je na početku imala naziv projekt-metoda ili metoda projekata. I danas se negde mogu naći ti nazivi. Zasnovanu na idejama Džona Djuia, metodu je prvo razvio Amerikanac V. Kilpatrik i ta koncepcija je prvi put primenjena još pre Prvog svetskog rata u školi-vežbaonici Kolumbija univerziteta u Njujorku. Takođe, ruski filozof A. V. Mihajlov odlučno je podržavao projektovanje kao metod saznavanja koji omogućava primenu znanja. Kraj 19. i početak 20. veka je period kada se uveliko radilo na razvoju projektne metode i u kom god pravcu da je kretao razvoj, u osnovi je stajala praktično otkrivanje znanja i primena tih stečenih znanja (Vilotijević i sar., 2018).

Glavne odlike projektne nastave su: usredsređenost na učenika, saradnički odnos učenika i nastavnika, bavljenje aktuelnom problematikom iz realnog života u okruženju, povezanost sa drugim naučnim područjima, saradničko timski rad, unapređivanje organizacijskih i komunikacijskih sposobnosti učenika i uvođenje novih metoda učenja. U projektu „Pansion Slobodan“ let nastojali smo da ostvarimo sve odlike koje smo gore naveli. Posebnu pažnju smo posvetili aktivnostima koje omogućavaju učenje svim čulima, pa smo kroz našu radionicu povezali kreativni, receptivni, produktivni i afektivni rad učenika ali i transmisiona uloga nasavnika ovde je skoro potpuno izostala, što i jeste jedna od osobina projektne nastave. Ovaj projekat za rezultat ima produkt koji ima jasnu upotrebnu i/ili vaspitnu vrednost.

\section{Kompetencije}

Razvijanje ključnih kometencija za celoživotno učenje, međupredmetnih i stručnih kompetencija, jedan je od ciljeva obrazovanja i vaspitanja u našoj zemlji, jer su preko potrebne za snalaženje i aktivno učešče u savremenom društvu koje se stalno i brzo menja.

Kompetencije predstavljaju skup povezanih znanja, veština, stavova i ličnih svojstava koje jednoj osobi omogućavaju da u datom kontekstu, u određenoj situaciji, preduzme odgovarajuću aktivnost i da je obavi valjano, uspešno i efikasno. Savremeni programi i sam proces učenja orijentisani su ka ishodima, kao i ka razvoju kompetencija koje su neophodne za buduće zanimanje učenika. Cilj je osposobiti učenike da naučeno primene u svakodnevnom životu, da mogu efikasno reagovati u novim situacijama, da rešavaju probleme, da budu aktivni učesnici u timskom radu.

Kompetencije koje se kroz nastavni proces razvijaju kod učenika, ne mogu se definisati jednom zauvek, niti ih je moguće sve jednako razviti. Zato je važno poznavati listu kompetencija i u skladu sa tim raditi na razvijanju onih za koje postoji potencijal kod učenika, ali i onih koje zahteva razvoj društva i društveno-ekonomske potrebe.

Kroz sve nastavne predmete možemo u manjoj ili većoj meri razvijati sve kompetencije, svesno ili nesvesno i omogućiti učenicima da steknu odgovarajuća znanja, stavove i veštine koji će im omogućiti primenu naučenog. Za razvoj kompetencija neophodno je obezbediti odgovarajuće okruženje, negovati istraživački rad i saradnju između učenika, primenjivati projektnu nastavu, gde je fokus pomeren sa realizacije sadržaja na aktivnosti učenika i samostalno učenje.

Svaki nastavni predmet daje svoj doprinos u razvijanju kompetencija. Pošto su rezultati obrazovanja vidljivi nakon veće vremenske distance od trenutka rada, često se postavlja pitanje da li i u kojoj meri razvijamo kompetencije učenika. Odgovor je u čitavom procesu. Ako se od učenika zahtevaju aktivnosti istraživanja, postavljanjem problema pred učenika, ako se obezbedi balans između grupnih i individualnih aktivnosti, ako se od učenika očekuje da istražuju, otkrivaju, da kreiraju nove produkte, da vrednuju svoja postignuća, onda smo na dobrom putu. Odgovornost je svakog nastavnika i svih predmeta da razvija kompetencije kod učenika koje će mu olakšati budućnost i pripremiti ih za nove 
izazove. Nećemo razviti u podjednakoj meri kompetencije kod svih učenika, kao što i svaki predmet ne razvija sve kompetencije $u$ istom odnosu, neke manje ili više, ali je konačan cilj povezati stečena znanja sa svakodnevnim životom.

\section{Opis radionice}

\section{Uvod u radionicu}

Nastavnici dele učenike u 4 grupe, po 4-5 učenika, i upoznaju ih kroz prezentaciju sa terminom hotel za insekte. Učenici, na osnovu fotografija, opisuju šta je hotel za insekte, prave poređenje sa kućicom za ptice, zašto je potreban hotel insektima, gde provode zimu, kada ih najčešće uočavaju u prirodi, zašto se postavljaju u baštama. Upoznati učenike kakva je povezanost gajenja lekovitog bilja u bašti i hotela za insekte, kakav je značaj hotela za insekte - da je hotel za korisne insekte, šta su korisni a šta štetni insekti, kakva je uloga pčela i bubamara u prirodi. Kroz primere obajsniti da se postavljanjem hotela za insekte povećava broj insekata oprasivača, da čuvaju bašte i uništavaju štetočine u baštama, da se upotrebom hotela za insekte smanjuje potreba za prskanjem voća ili kultura u baštama.

\section{Praktičan rad}

Sledi izrada hotela od gotovih delova po principu slagalice. Podeliti materijal za rad. Svaka grupa dobija jedan prazan osnovni veći oblik za hotel napravljen od fino obrađenih drvenih letvica. Osnovni oblik hotela mogu i sami da odaberu ukoliko izraze zelju za tim. Na jednom mestu nalaze se svi ostali delovi kojima se popunjava unutrasnjost osnovnog oblika. Učenicima je na raspolaganju veliki broj gotovih drvenih delova pravilnog i nepravilnog oblika, različitih dimenzija, sa već izbušenim otvorima za insekte. Delovi se lako kombinuju i uklapaju u osnovni oblik hotela. Učenici po sopstvenoj želji i proceni uklapaju ponuđene oblike formirajući unikatan hotel za insekte. Mogu koristiti i slamu, grančice, karton, razmenjivati delove za slaganje. Nastavnici i učitelji pomažu pri izradi i usmeravaju rad učenika. Učenici treba da primete da su otvori za ulaz insekata različitih veličina i oblika. Diskutuju o tome šta sve možemo koristiti od materijala, da li insekti razlikuju boje, koji materijal koristiti da bi privukli veći broj insekata. Treba da zaključe da su prirodni materijali najbolji za ovu vrstu hotela.

Na kraju radionice svaka grupa opisuje svoj hotel, navodi koji bi insekti živeli u njihovom hotelu, šta bi im ponudili, zašto su koristili materijal različitih boja, da li insekti razlikuju boje, pozvati ih da naprave hotel za insekte, samostalno istražuju, prate i doprinose povećanju broja insekata i njihovom očuvanju. Predložiti učenicima da u svojoj bašti ili voćnjaku naprave samostalno hotel za insekte i da samostalno prate, zapisuju, opisuju, vode dnevnik koje vrste insekata dolaze da se hrane i prespavaju zimu.

\section{Zaključak}

Projektna nastava je do sada najbolji način za razvoj predmetnih i međupredmetnih kompetencija. Kroz realizaciju projektnih aktivnosti podsiče se timski rad i saradnički odnos, zajedničko traganje i pronalaženje rešenja, povezivanje sa primerima iz svakodnevnog života i primena u svakodnevnom životu. Jedan od ciljeva ove radionice je razvijanje kompetencije za saradnju i komunikaciju. Izradom hotela za insekte kod učenika se razvija estetička, a pre svega preduzetnička kompetencija. Posmatranjem i praćenjem insekata, učenici osvešćuju svoje znanje o položaju i ulozi insekata u prirodi, čime se razvija kako kompetencije za odgovoran odnos prema okolini, tako i za odgovoran odnos prema zdravlju. Radionica treba da skrene pažnju da i kroz vannastavne aktivnosti i 
kroz projektnu nastavu podstičemo razvoj međupredmetnih kompetencija koje su učenicima neophodne u daljem radu.

Kakav je značaj insekata govori činjenica da postoji zasebna disciplina koja se bavi proučavanjem ove najbrojnije klase životinja. Njihov značaj je veliki. U lancu su ishrane, oprašivači su, poboljsavaju kvalitet zemljišta, značajni su čistači prirode, doprinose kruženju materije u prirodi, smanjuju brojnost štetnih insekata. lako među njima ima i štetočina, to ne umanjuje njihov značaj, naprotiv. To je još jedan razlog da se bavimo insektima, jer je moguća i važna biološka kontrola insekata štetočina, radi postizanja ravnoteže u ekosistemu.

S obzirom na to da veliki broj biljnih vrsta koje se koriste u ljudskoj ishrani, ne bi postojao da nema korisnih insekata, to je već i više nego dovoljan razlog u što ranijem uzrastu razvijati svest kolektiva i pojedinca o očuvanju prirode, kroz kolektivne i individualne aktivnosti. Jednostavnim radionicama kod učenika je lako probuditi radoznalost, ali i osećaj odgovornosti za prirodu. Potrebno je da učenici shvate važnost postojanja insekata na planeti Zemlji i osvestiti saznanje da ukoliko ne bude bilo insekata neće postojati ni ljudska vrsta.

\section{Korišćena literatura}

Popović D. i Ristanović D. (2020). Potencijali projektne nastave za razvijanje međupredmetnih kompetencija. Uzdanica, XVII/2, 281-294.

Pravilnik o opštim standardima postignuća za kraj opšteg srednjeg obrazovanja i srednjeg stručnog obrazovanja u delu opšteobrazovnih predmeta (2013). Službeni glasnik RS, br. 117/2013.

Standardi opštih međupredmetnih kompetencija za kraj srednjeg obrazovanja (2013). Beograd: Zavod za vrednovanje kvaliteta obrazovanja i vaspitanja.

Subakov Simić, G. i Drndarski, M. (2018). Biologija za 5.razred. Beograd: Novi Logos.

Subakov Simić, G. i Drndarski, M. (2019). Biologija za 6.razred. Beograd: Novi Logos.

Vilotijević M., Vilotijević N. i Mandić D. (2018). Projektna nastava u IKT okruženju. Beograd: Učiteljski fakultet.

www.agromedia.rs/agro-teme/organska-proizvodnja/hotel-za-insekte-zasto-je-sve-popularniji-kod-povrtara-siromsveta/. Preuzeto 30. maja 2021. 


\title{
Insects' Hotel - Development of Cross-Curricular Competencies Through Project Teaching
}

\author{
Ana R. Jeremić \\ PHS „Dr Đorđe Radić“ Kraljevo i OŠ „IV kraljevački bataljon“, Kraljevo, Serbia \\ Nataša M. Vukovič \\ OŠ „IV kraljevački bataljon“, Kraljevo, Serbia
}

\begin{abstract}
In the conditions of dynamic social and technological changes it is necessary to introduce a more engaged process of knowledge construction in a realistic environment, (Popović, Ristanović 2020). Project based learning is a form of teaching that enables the development of subjects' and interdisciplinary competencies necessary for functioning in real life conditions. In this paper an example of good practice is described, i.e., course of the workshop, planned and realized within the project based learning. The workshop is intended for students of primary school in grades 4,5 and 6 with the goal of bringing students closer to information about the importance and position of insects in nature through creative workshops - by making a hotel for insects. The activities are designed to arouse students' interest in nature and science, to have fun and to develop awareness of the importance of insects in nature, as well as the endangerment of some species, through play and wooden constructions. Also, one of the goals is to independently devise a way to increase the number of insects, to discover why insects are important for maintaining balance in nature, to devise how to make a hotel for insects in their garden and which materials to use for it, to develop interest and motivation for observation, learning and protection of insect species in their natural habitat.
\end{abstract}

Key words: project based learning, subjects and interdisciplinary competencies, workshop, hotel for insects. 